\title{
AKUNTANSI KETOPRAK: SEBUAH PENDEKATAN ETNOGRAFI MASYARAKAT SENI KETOPRAK DI PATI
}

\author{
Purweni Widhianningrum dan Nik Amah \\ Program Studi Pendidikan Akuntansi-FPIPS \\ IKIP PGRI MADIUN \\ sigmaku87@gmail.com
}

\begin{abstract}
Abstrak
Penelitian ini bertujuan untuk menggambarkan dan memaknai praktik akuntansi pada masyarakat seni budaya ketoprak di Pati, dan untuk mengetahui rekonstruksi konsep akuntansi pada masyarakat seni budaya ketoprak yang sarat dengan nilai budaya lokal. Ketoprak (bahasa Jawa: kethoprak) adalah seni pertunjukan rakyat tradisional yang menampilkan sandiwara diselingi dengan lagu-lagu Jawa dan diiringi gamelan (alat musik tradisional Jawa). Seni ketoprak yang ada di Pati kebanyakan adalah ketoprak tanggapan yaitu ketoprak yang dihelat karena adanya permintaan pada suatu hajatan. Penulis mengamati seni ketoprak di Pati sebagai sebuah organisasi dan sarana penghidupan bagi seniman yang tergabung dalam grup seni ketoprak tersebut. Data diperoleh dari informan (anggota dari kelompok budaya seni ketoprak di Pati) melalui pengamatan berpartisipasi, wawancara mendalam dengan para informan dan dokumentasi. Hasil penelitian menunjukkan bahwa kompensasi ekonomi yang diperoleh hanyalah sebagai sarana untuk melestarikan serta menjamin kelangsungan hidup kelompok seni ketoprak. Hasil rekonstruksi konsep akuntansi pada masyarakat seni budaya ketoprak menunjukkan bahwa akuntansi dipandang sebagai kegiatan pencatatan yang berhubungan dengan angka serta kalkulasi dalam kegiatan ekonomi yang sarat dengan nilai kejujuran serta tanggung jawab.
\end{abstract}

Kata kunci: Akuntansi, Ketoprak, dan Etnografi

\section{PENDAHULUAN}

Banyak budaya warisan leluhur yang menjadi daya tarik dan ciri khas masing-masing daerah. Daya tarik dan ciri khas ini merupakan asset yang sangat berharga dan merupakan sumber kekayaan yang tiada habis bilamana kita bangsa Indonesia mampu melestarikan dan mengelolanya. Namun tanpa disadari oleh masyarakat, era globlisasi turut membawa budaya luar mengancam hilangnya jati diri bangsa Indonesia. Budaya daerah sebagai bagian budaya nasional merupakan indentitas bangsa Indonesia akan semakin terkikis dan hilang jika pembinaan dan apresiasi terhadapnya semakin kecil.

Menurut Pradhana (2013) kesenian sebagai unsur kebudayaan dapat digunakan sebagai sarana untuk mengungkapkan perasaan yang dialami atau peristiwa yang tengah terjadi di masyarakat. Selanjutnya kesenian juga memiliki fungsi untuk menambah kenikmatan pada hidup sehari-hari, menentukan norma perilaku yang teratur, dan meneruskan adat kebiasaan serta nilai-nilai kebudayaan 
kepada generasi selanjutnya (Havilland dalam Pradhana, 2013 dan Soedarsono,1999). Indonesia memiliki beraneka ragam suku bangsa sudah pasti memiliki keanekaragaman kesenian budaya pula. Masing-masing suku dan bahkan di masing- masing daerah memiliki keunikan yang menjadi potensi wisata budaya yang menarik jika dikelola dengan optimal. Wujud dari hal tersebut bisa berupa barang-barang bernilai seni (batik, songket ataupun kerajinan seni lain), atau juga seni pertunjukan. Suku Jawa adalah salah satu suku bangsa Indonesia yang memiliki kekayaan khasanah budaya daerah yang masih kita kenal hingga sekarang. Banyak daerah di Jawa yang masih berupaya melanggengkan eksistensi kesenian tradisional seperti halnya seni pertunjukan, seni tari tradisional, serta seni musik daerah dengan penggunaan alat musik tradisional. Kesenian tradisional, diantaranya seni pertunjukan rakyat tradisional memiliki fungsi, baik secara ritual maupun sebagai hiburan masyarakat (Ravhani dan Muryadi, 2012). Seni pertunjukan memiliki fungsi ritual sebagai prasyarat dalam suatu acara ataupun upacara adat. Sedangkan fungsi seni pertunjukan sebagai hiburan dikemas dan ditampilkan secara estetis dan memiliki nilai jual.

Beberapa contoh seni pertunjukan rakyat tradisional yang berkembang di Jawa Tengah meliputi wayang kulit, wayang orang, dan ketoprak. Karena pengaruh arus budaya global yang beralasan modernisasi banyak seni pertunjukan rakyat tradisional yang tersisih sebagai contohnya ketoprak. Ketoprak adalah salah satu kesenian tradisional yang sarat akan nilai kearifan lokal (local wisdom). Sebagaimana pernyataan Basuki (2007) bahwa ketoprak sebagai salah satu bentuk seni pertunjukkan tradisional Jawa Tengah telah mampu mengundang perhatian masyarakat penikmat di berbagai pelosok pulau Jawa. Ini tidak terlepas dari kemampuan ketoprak untuk menggambarkan cerita yang telah berakar, bersumber pada keteladanan yang luhur bangsa Indonesia pada masa silam, selain itu juga ketoprak merupakan refleksi kehidupan sehari-hari bagi masyarakat Jawa pada khususnya.

Semakin tersisihnya ketoprak hampir terjadi di seluruh wilayah kultural kebudayaan Jawa (Jokomono, 2008). Di daerah-daerah di Jawa Tengah sudah jarang seni pertunjukan rakyat tradisional ketoprak digelar. Hanya sebagian kecil daerah saja yang masih menggelar ketoprak sebagai hiburan maupun sebagai prasyarat dalam suatu acara ataupun upacara adat seperti halnya sedekah bumi. Pati dengan sebutan Bumi Mina Tani adalah salah satu daerah di Jawa Tengah yang masyarakatnya masih menunjukkan kepedulian dan memberikan apresiasi terhadap seni ketoprak.

Keberadaan 10 group seni ketoprak dengan kategori laris tanggap tersebut menunjukan bahwa seni ketoprak masih bertahan di Bumi Mina Tani. Namun demikian, eksistensi seni pertunjukan tradisional ini juga pasti mengalami pasang surut. Pasang surut pada seni pertunjukan ketoprak disebabkan oleh faktor- faktor pendukung dan penghambat. Eksistensi seni pertunjukan ketoprak akan sangat tergantung pada apresiasi masyarakat untuk senantiasa mendukung kesenian 
ketoprak. Masyarakat memberikan apresiasi berupa masukan atau menanggap ketoprak saat acara ataupun upacara tertentu sebagai salah satu upaya pelestarian. sebaliknya, seni pertunjukan ketoprak akan terhambat karena perkembangan era kesenian modern. Selain itu juga karena kurangnya peran pemerintah daerah dalam memberikan apresiasi serta kontribusi sehingga terkesan ketoprak menjadi kesenian individual. Seyogyanya pemerintah daerah mendukung penuh serta memberikan ruang apresiasi tinggi bagi kelangsungan grup ketoprak ataupun wadah yang mengakomodir kepentingan pelestarian seni ketoprak

Soedarsono (1998), menyebutkan bahwa hidup dan matinya sebuah seni pertunjukan disebabkan oleh bermacam-macam hal. Penyebabnya meliputi masalah ekonomi, dan perubahan selera masyarakat penikmat seni ketoprak yang pada akhirnya membuat seni pertunjukan ketoprak tidak mampu bersaing dengan seni pertunjukan yang lain. Perkembangan seni pertunjukan bisa juga dilihat dari siapa yang menjadi penyandang dana produksinya. Dalam rangka pelestarian seni pertunjukan tradisional ketoprak dibutuhkan tidak hanya tenaga, pemikiran, waktu, kemauan, namun juga modal. Modal menjadi hal vital yang dibutuhkan dalam upaya pelestarian seni pertunjukan tradisional ketoprak serta menjamin kelangsungan hidup grup seni ketoprak.

Penulis mengamati seni ketoprak di Pati sebagai bentuk usaha dan sarana penghidupan bagi seniman yang tergabung dalam kelompok seni ketoprak tersebut. Sebagai sebuah organisasi, grup seni ketoprak membutuhkan pengelolaan diantaranya pengelolaan keuangan (angka-angka akuntansi) demi keberlangsungan seni pertunjukan ketoprak selanjutnya. Sukoharsono (2010) mengungkapkan bahwa akuntansi merupakan disiplin ilmu dan praktek yang terbentuk dan berkembang sebagai praktek sosial di tengah masyarakat serta dianggap memberikan kontribusi yang besar bagi kesejahteraan masyarakat dalam jangka panjang.

Penelitian tentang praktik akuntansi dengan menggunakan pendekatan kualitatif telah banyak dilakukan oleh para peneliti, seperti Sukoharsono (2009), Rahayu, Ludigdo, dan Affandy (2007), Sukoharsono dan Qudsi (2008), Razak, Ludigdo, Sukoharsono, dan Thoyib (2011), Budiasih dan Sukoharsono (2012), dan Sukoharsono dan Putra (2013). Hasil studi Sukoharsono (2009) menyimpulkan bahwa akuntansi telah dipahami sebagai bentuk lain dari sosial kemasyarakatan yang syarat nilai-nilai sosial, politik dan budaya. Sehingga ethnografi kritis yang merupakan alternatif suatu studi tentang kebudayaan atau fenomena sosial antar manusia dan kelompok-kelompok dapat dapat dipilih sebagai teknik riset yang memberikan perhatian pada banyak perspektif, ketidak setaraan budaya dan sosial serta diarahkan pada perubahan sosial dapat memberikan makna yang berbeda.

Berdasarkan latar belakang masalah yang telah dipaparkan di atas, maka penelitian ini berusaha untuk menjawab pertanyaan sebagai berikut: (1) Bagaimana pemaknaan akuntansi pada masyarakat seni ketoprak di Pati?; (2) 
Bagaimana rekonstruksi konsep akuntansi masyarakat seni ketoprak di Pati yang sarat dengan nilai budaya lokal?

Tujuan yang ingin dicapai dari penelitian ini adalah untuk menggambarkan dan memaknai praktik akuntansi pada masyarakat seni budaya ketoprak di Pati, sehingga diketahui rekonstruksi konsep akuntansi pada masyarakat seni budaya ketoprak yang sarat dengan nilai budaya lokal.

\section{METODE PENELITIAN}

Obyek dari penelitian ini adalah manusia, sehingga peneliti merasa lebih tepat jika menggunakan penelitian kualitatif. Penelitian kualitatif adalah penelitian yang menggunakan pendekatan naturalistik untuk mencari dan menemukan pengertian atau pemahaman tentang fenomena dalam suatu latar yang berkonteks khusus (Moleong, 2009: 6)

Paradigma yang digunakan dalam penelitian ini adalah paradigma interpretif. Paradigma interpretif lebih menekankan pada realitas sosial yang secara sadar dan secara aktif dibangun sendiri oleh individu-individu (Soetriono dan Hanafie, 2007). Pendekatan yang digunakan adalah etnografi. Pendekatan etnografi bertujuan untuk mempelajari peristiwa kultural yang menyajikan pandangan hidup subjek yang menjadi objek studi. Studi etnografi merupakan salah satu deskripsi tentang cara mereka berfikir, hidup, dan berperilaku (Muhajir, 2007:147)

\section{PENGUMPULAN DATA}

Penelitian ini dilakukan pada salah satu kelompok budaya seni ketoprak di Jawa Tengah, yaitu Kelompok Ketoprak Wahyu Budoyo yang berada di Ngangel, Dukuhsekti, Kota Pati. Obyek analisis pada penelitian ini adalah realitas kelompok budaya daerah sebagai sebuah komunitas, yang di dalamnya terjadi interaksi antara individu dan struktur. Kelompok seni yang dipilih sebagai obyek analisis adalah salah satu grup seni ketoprak dengan dengan kategori laris tanggap. Informan untuk penelitian ini adalah para pelaku seni ketoprak yang terlibat langsung dan mempunyai pengalaman dalam proses penyusunan laporan keuangan. Identitas informan yang digunakan hanya inisial untuk menggantikan nama informan yang sebenarnya.

Pengumpulan data dilakukan melalui wawancara mendalam dengan para informan dan didukung dengan pengamatan berpartisipasi dan dokumentasi. Wawancara dilakukan secara tidak terstruktur dan informal dalam berbagai situasi. Pengamatan berpartisipasi dilakukan dengan cara keterlibatan peneliti dalam proses analisis dengan informan yang memiliki wewenang membuat catatan keuangan selama rentang waktu kurang lebih enam bulan. Dokumentasi digunakan untuk mengungkap realitas sosial yang terdapat dalam suatu dokumen. 


\section{HASIL DAN PEMBAHASAN}

Pemaknaan praktik akuntansi yang diperoleh peneliti dari kelompok seni ketoprak menunjukkan bahwa kompensasi ekonomi yang diperoleh setiap kali pertunjukkan usai dimaknai sebagai sarana untuk melestarikan serta menjamin kelangsungan hidup kelompok seni ketoprak. Pendapatan kelompok seni ketoprak dalam sekali tanggapan dikelola oleh seorang anggota pemain ketoprak sekaligus memiliki wewenang untuk mengelola kekuangan (angka-angka akuntansi) kelompok seni tersebut. Dari hasil tanggapan tersebut kemudian diklasifikasikan ke dalam dua pos, yang disebutnya sebagai "belonjo" dan "uang kas". Belonjo merupakan pengeluaran uang dari hasil tanggapan untuk membiayai honor pemain bala kepruk (peran prajurit), bala mbok mban (peran dayang), pemain inti (pemeran inti), niyaga (penabuh gamelan), sindhen, bagian teknik dan soundsystem (tata panggung dan musik) setelah dikurangi pengeluaran lain selama tanggapan (biaya perjalanan dan makan). Uang kas merupakan sisa hasil tanggapan setelah dikurangi dengan "belonjo”. Uang kas ini biasanya digunakan untuk pemeliharaan peralatan dan perlengkapan pentas ketoprak (gamelan, kostum, perangkat musik tradisional dan modern) serta membiayai acara paguyuban guna mempererat tali silaturahmi di antara pimpinan dan para pemain anggota grup. Seperti yang diungkapkan oleh "juru catet”, salah seorang anggota kelompok yang berwewenang melakukan pencatatan keuangan, berikut ini:

"nggeh wonten.. mriki wonten catetan khusus damel nyatet arta ingkang mlebet saha ingkang medal. Catetanipun nggeh arupo catetan arta ingkang mlebet saking sumber tanggapan lajeng dipunwedalaken damel belanjane poro pemain, nggeh bala kepruk, bala mbok mban, pemain inti, niyaga, sindhen, bagian teknik ingkang noto panggung kaliyan sound, lan sapiturutipun. Benten meleh kaliyan catetanipun damel nyatet uang kas. Uang kas niko nggeh sumberipun saking arta tanggapan. Sakmangke bos e angsal lunasan arta tanggapan, biasane niko lajeng dipunsisihke sekedik damel uang kas ngoten. Uang kas ipun biasane kagem mbiayai acara - acara paguyuban ingkang saget ngraketaken paseduluran antaranipun pimpinan kaliyan poro pemain anggota grup ketoprak Wahyu Budoyo. Selain kagem mbiayai acara paguyuban, uang kas ipun nggeh damel cadangan mbok menawi kala-kala alat-alatipun kados to gamelan nopo tape nopo sound ipun onten ingkang rusak ngoten."

Dari segi ekonomi, pementasan ketoprak memiliki keunikan tersendiri. Pada saat pementasan berlangsung, penonton kerap kali memberikan "saweran" berupa uang secara sukarela pada pemain ketoprak (terutama pada saat tarian). Setelah pertujukan ketoprak usai, hasil "saweran" tersebut kemudian dibagi rata antar anggota kelompok. Memang pendapatan materi tersebut tidak sebanding 
dengan jerih payah mereka selama menjalankan latihan, namun mereka menganggap bahwa "saweran' tersebut merupakan bentuk apresiasi penonton terhadap perjuangan kelompok seni mempertahankan dan melestarikan budaya seni ketoprak.

"Grup Ketoprak Wahyu Budoyo dipun jumenengaken supados saget nguri-uri kabudayan Jawi, terutama nggih meniko pentas ketoprak. Kulo sampun kaleh dasa tahun tumut mriki (Wahyu Budoyo). Kulo saestu remen lan bangga dados pemain ketoprak. Kala riyin wanci kulo taksih lare, kulo dipuntepangaken ketoprak dateng suwargi bapak. Suwargi bapak kulo nggih pemaen ketoprak. Dados pemaen ketoprak pancen mboten sepinten angsale belanjane niko, tapi nggeh kedah dipun syukuri. Kulo tumut mriki amargi katresnan kulo marang seni ketoprak. Nggih amrihe kulo saget nguri - uri kabudayan Jawi, nguri - uri warisanipun leluhur supados mboten ical musna kelindes jaman lan kabudayan luar"

Berdasarkan penuturan salah seorang pemain ketoprak di atas, dapat ditarik kesimpulan bahwa masyarakat seni yang tergabung ke dalam kelompok seni ketoprak sejatinya dalam menjalankan profesi seni tersebut merupakan bentuk kecintaan mereka terhadap seni budaya pertunjukan tradisional Jawa yaitu ketoprak. Kesenian ketropak sudah menjadi bagian hidup dari para pemainnya. Mereka menganggap bahwa budaya jawa sarat dengan nilai-nilai budaya lokal yang telah mengajarkan bagaimana pandangan hidup orang-orang di tanah Jawa berdampingan dengan sesama, alam, dan Sang Khalik. Pada umumnya, ketoprak di Pati menceritakan lakon-lakon Babad Jawa (kerajaan) serta konflik sederhana seputar kehidupan sehar-hari masyarakat desa.

Rekonstruksi konsep akuntansi pada masyarakat seni budaya ketoprak menunjukkan hasil bahwa akuntansi dipandang sebagai kegiatan pencatatan yang berhubungan dengan angka serta kalkulasi dalam kegiatan ekonomi yang sarat dengan nilai kejujuran serta tanggung jawab. Prinsip kejujuran dan tanggung jawab tersebut yang kemudian dimaknai oleh kelompok seni dalam kegiatan berkesenian sebagai wujud tanggung jawab setiap anggota terhadap diri sendiri, keluarga, pemimpin kelompok, dan leluhur untuk melestarikan budaya dalam kehidupan sehari-hari yang sejajar dengan nilai-nilai budaya lokal (keseimbangan hubungan antara sesama, alam, dan Sang Khalik) masyarakat Pati khususnya seni pertunjukkan ketoprak.

\section{KESIMPULAN}

Ketoprak (bahasa Jawa: kethoprak) merupakan seni pertunjukan rakyat tradisional yang menampilkan sandiwara diselingi dengan lagu-lagu Jawa dan 
diiringi gamelan (alat musik tradisional Jawa). Seni ketoprak di Pati yang sebagian besar merupakan ketoprak tanggapan, membutuhkan pengelolaan diantaranya pengelolaan keuangan (angka-angka akuntansi) demi keberlangsungan seni pertunjukan ketoprak selanjutnya.

Hasil penelitian menunjukkan bahwa kompensasi ekonomi yang diperoleh setiap kali pertunjukkan usai dimaknai sebagai sarana untuk melestarikan serta menjamin kelangsungan hidup kelompok seni ketoprak. Masyarakat seni yang tergabung ke dalam kelompok seni ketoprak sejatinya dalam menjalankan profesi seni tersebut merupakan bentuk kecintaan mereka terhadap seni budaya pertunjukan tradisional Jawa yaitu ketoprak. Mereka menganggap bahwa budaya jawa sarat dengan nilai-nilai budaya lokal yang telah mengajarkan bagaimana pandangan hidup orang-orang di tanah Jawa berdampingan dengan sesama, alam, dan Sang Khalik. Sedangkan rekonstruksi konsep akuntansi pada masyarakat seni budaya ketoprak menunjukkan hasil bahwa akuntansi dipandang sebagai kegiatan pencatatan yang berhubungan dengan angka serta kalkulasi dalam kegiatan ekonomi yang sarat dengan nilai kejujuran serta tanggung jawab.

\section{DAFTAR PUSTAKA}

Basuki, Agus R. 2007. Peranan Tindak Tutur dalam Seni Pertunjukan Ketoprak. Seni Budaya, Vol. 1, No. 21. http://repo.isi-dps.ac.id/507/ diunduh pada 20 November 2013.

Budiasih, I Gusti Ayu Nyoman dan Eko Ganis Sukoharsono. 2012. Accounting Practices and The Use of Money in The Reign of King Udayana in Bali: An Ethnoarcheological Approach. Simposium Nasional Akuntansi XV, Banjarmasin, 20 - 23 September.

Jokomono. 2008. Di Pati, Ketoprak Tak Mati. http://suaramerdeka.com/v1/index.php/read/cetak/2008/02/24/2255/DiPati-Ketoprak-Tak-Mati. Diunduh pada 20 November 2013.

Moleong, Lexy. 2009. Metodologi Penelitian Kualitatif. Bandung: Remaja Rosdakarya.

Muhajir, Noeng. 2007. Metodologi Keilmuan Paradigma Kualitatif, Kuantitatif dan Mixed. Yogyakarta: Rake Sarasin.

Pradhana, Erry C.A. 2013. Fungsi Seni Tayub Dalam Masyarakat Di Dusun Ngrajek Desa Sambirejo Kecamatan Tanjung Anom Kabupaten Nganjuk. AntroUnairDotNet, Vol. 2, No. 1 Pebruari.

Rahayu, Sri, Unti Ludigdo, Didiet Affandy. 2007. Studi Fenomenologis Terhadap Proses Penyusunan Anggaran Daerah Bukti Empiris Dari Satu Satuankerja Perangkat Daerah Di Provinsi Jambi. Seminar NAsional Akuntansi (SNA) X. Unhas Makasar.

Ravhani, Suhardiyanti E. dan Muryadi. 2012. Ketoprak Siswo Budoyo Tulungagung: Riwayat Perjalanan dan Kontribusinya Tahun 1958 - 1995. Verleden, Vol. 1, No. 1 Desember.

Razak, A., Unti Ludigdo, Eko Ganis Sukoharsono, dan Armanu Thoyib. 2011. Perilaku Kuasa Eksekutif dan Legislatif Dalam Proses Penyusunan Anggaran Pemerintah Daerah: Perspektif Interaksionisme Simbolik. 
Jurnal Akuntansi Multiparadigma, Volume2, Nomor3, Desember 2011, Hlm. 492-509.

Salim, P. 1991. Kamus Bahasa Indonesia Kontemporer. Jakarta: Modern English Press.

Soedarsono, R. M. 1998. Seni Pertunjukan Indonesia Di Era Globalisasi. Jakarta: Direktorat Jenderal Pendidikan Tinggi Departemen Pendidikan dan Kebudayaan.

Soedarsono, R. M. 1999. Seni Pertunjukan Indonesia dan Pariwisata. Yogyakarta: Arti.Line

Soetriono dan Rita Hanafie. 2007. Filsafat Ilmu dan Metodologi Penelitian. Yogyakarta: Andi.

Soetriono dan Rita Hanafie. 2007. Filsafat Ilmu dan Metodologi Penelitian. Yogyakarta: Andi.

Sukoharsono, Eko Ganis dan Novrida Qudsi. 2008. Accounting in the Golden Age of Singosari Kingdom: A Foucauldian Perspective. Simposium Nasional Akuntansi XI, Pontianak.

Sukoharsono, Eko Ganis dan Nuruddin Ahmad Putra. 2013. Creating Shared Value (CSV) Rural Development Sector at PT Nestle Kejayan Factory: An Ethnographical Study of Jabung Agro Niaga Cooperative and Pujon SAE Cooperative as a Reference Development of Corporate Social Responsibility (CSR) Based on Social Entrepreneurship. Proceeding of Brawijaya International Conference on Accounting and Business, University of Brawijaya, Malang, 29-30 August.

Sukoharsono, Eko Ganis. 2009. Refleksi Ethnografi Kritis: Pilihan Lain Teknik Riset Akuntansi. Jurnal Akuntansi dan Bisnis Vol. 4, No. 1.

Sumaryadi, Adi. 2013. Indonesia peringkat 39 dunia soal budaya. http://www.adisumaryadi.net. Diunduh pada 20 November 2013. 


\title{
PENGARUH PENGGUNAAN TEKNOLOGI INFORMASI \\ DAN MINAT PEMANFAATAN TEKNOLOGI INFORMASI TERHADAP KINERJA PEGAWAI DI BKKBN KABUPATEN MADIUN
}

\author{
Tuti Hariyani \\ Magister Akuntansi Universitas Sebelas Maret \\ bagindaeka@gmail.com
}

\begin{abstract}
ABSTRAK
Agar teknologi informasi dapat meningkatkan kinerja organisasi atau institusi yang melakukan investasi, teknologi ini harus dapat diterima dan digunakan terlebih dahulu oleh pemakai-'pemakainya sehingga besarnya dana yang dipakai dalam melakukan investasi atas teknologi informasi, akan diimbangi dengan kinerja individual anggota organisasi atau institusinya. Metode penelitian yang digunakan adalah explanative research. Populasi penelitian adalah pegawai BKKBN Kabupaten Madiun yang berjumlah 32 orang. Teknik sampling adalah purposive sampling dan menggunakan alat uji statistik Regresi Linier, dengan variabel independen Penggunaan Teknologi Informasi dan Minat Pemanfaatan Teknologi Informasi, serta variabel dependen Kinerja Pegawai BKKBN. Hasil dari penelitian ini adalah dari 32 responden diketahui bahwa nilai t hitung variabel Penggunaan Teknologi Informasi adalah 1,880 dengan tingkat signifikansi sebesar 0,039., hal ini disimpulkan bahwa terdapat pengaruh secara parsial variabel Penggunaan Teknologi Informasi terhadap variabel terikat Kinerja Pegawai BKKBN, nilai t hitung variabel Minat Pemanfaatan Teknologi Informasi adalah 2,922 dengan tingkat signifikansi sebesar 0,007, hal ini disimpulkan bahwa terdapat pengaruh yang signifikan antara variabel bebas Minat Pemanfaatan Teknologi Informasi terhadap variabel terikat Kinerja Pegawai BKKBN Kabupaten Madiun.

Berdasarkan hasil penelitian, dapat disimpulkan bahwa terdapat pengaruh antara Penggunaan Teknologi Informasi dan Minat Pemanfaatan Teknologi Informasi terhadap Kinerja Pegawai BKKBN Kabupaten Madiun
\end{abstract}

Kata kunci: Penggunaan Teknologi Informasi, Minat Pemanfaatan Teknologi Informasi, Kinerja

\section{PENDAHULUAN}

Teknologi informasi khususnya teknologi komputer sangat berpotensi untuk memperbaiki performa individu dan organisasi, karenanya banyak pengambil keputusan menginvestasikan dana untuk teknologi informasi. Menurut Sungmin Kang (1998), teknologi informasi akan membantu perusahaan untuk memperbaiki performance organisasi, hanya apabila perusahaan menggunakan teknologi informasi secara aktual dalam langkah yang efisien, sehingga penerapan teknologi baru dalam suatu organisasi akan berpengaruh pada keseluruhan organisasi, terutama pada sumber daya manusia.

Agar teknologi informasi dapat meningkatkan kinerja organisasi atau institusi yang melakukan investasi, teknologi ini harus dapat diterima dan 
digunakan terlebih dahulu oleh pemakai-'pemakainya sehingga besarnya dana yang dipakai dalam melakukan investasi atas teknologi informasi, akan diimbangi dengan kinerja individual anggota organisasi atau institusinya secara signifikan. Menurut Lucas dan Spitler (1999), agar teknologi informasi dapat diterapkan secara efektif sehingga dapat memberikan kontribusi terhadap kinerja maka anggota dalam organisasi harus dapat menggunakan teknologi tersebut dengan baik dan memberikan kontribusi terhadap kinerjanya. Sedangkan menurut Goodhue dan Thomson (1995), agar suatu teknologi informasi memberikan dampak yang positif terhadap kinerja individual maka teknologi tersebut harus dimanfaatkan dengan tepat dan harus mempunyai kecocokan dengan tugas yang dilakukannya.

\section{TINJAUAN PUSTAKA}

Menurut McKeown (2001) yang dimaksud dengan teknologi informasi adalah "teknologi informasi merujuk pada seluruh bentuk teknologi yang digunakan untuk menciptakan, menyimpan, mengubah dan menggunakan informasi dalam segala bentuknya." Dalam Kamus Oxford (Kadir, 2003), teknologi informasi didefinisikan sebagai studi atau penggunaan peralatan elektronika, terutama komputer untuk menyimpan, menganalisa dan mendistribusikun informasi apa saja, termasuk kata-kata, bilangan dan gambar. Secara umum Lucas (2000) menyatakan bahwa teknologi informasi adalah segala bentuk teknologi yang diterapkan untuk memproses dan mengirimkan informasi dalam bentuk elektronis. Menurut Senn (2004), teknologi informasi didefinisikan sebigai sebuah istilah yang merujuk ke hal-hal dan keahlian yang digunakan daiam ponciptaan, penyimpanan, penyebaran

Dalam model teknologi informasi, O'Brain (2008) menyebutkan bahwa teknologi informasi bergantung pada sumber daya manusia, perangkat keras (hardware), perangkat lunak (software), data (data dan pengetahuan dasar) serta jaringan (media komunikasi dan dukungaI jaringan). Teknologi Informasi meliputi teknologi komputer (computing technology) dan teknologi komunikasi (communication technology) yang digunakan untukt memproses dan menyebarkan informasi baik yang bersifat finansial atau nonfinansial. Teknologi informasi dalam perusahaan berfungsi sebagai alat bantu pencapaian tujuan melalui penyediaan informasi. Kesuksesan teknologi informasi dapat diukur dengan empat jenis ukuran yaitii kepuasan pemakai, penggunaan sistem, kinerja keputusan, dan kinerja organisasi.

Minat seseorang terhadap suatu objek akan lebih kelihatan apabila objek tersebut sesuai sasaran dan berkaitan dengan keinginan dan kebutuhan seseorang yang bersangkutan (Sardiman, 1990). Menurut Tampubolon (1991) mengatakan bahwa minat adalah suatu perpaduan keinginan dan kemauan yang dapat berkembang jika ada motivasi. Sedangkan menurut Djali (2008) bahwa minat pada dasarnya merupakan penerimaan akan sesuatu hubungan antara diri sendiri dengan sesuatu di luar diri. Menurut Thompson et.al. (2001), pemanfaatan teknologi informasi merupakan hal yang diharapkan oleh pengguna sistem informasi dalam melaksanakan tugasnya, dimana pengukurannya berdasarkan intensitas pemanfaatan, frekuensi pemanfaatan dan jumlah aplikasi atau perangkat lunak yang digunakan. 
Pemanfaatan teknologi juga berhubungan dengan perilaku menggunakan teknologi tersebut daiam menyelesaikan tugas. Theory of Reasoned Action (TRA) adalah suatu teori yang berhubungan dengai sikap dan perilaku individu daiam melaksanakan kegiatan. Seseorang akan memanfaatkan teknologi informasi dengan alasan bahwa teknologi tersebut akan menghasilkan manfaat bagi dirinya. Sheppard et al. (1988) menyatakan bahwa TRA telah digunakan untuk memprediksi suatu perilaku dalam banyak hal.

\section{METODE PENELITIAN}

Rancangan penelitian ini merupakan tipe penelitian penjelasan (explanatif research) dengan melakukan pengamatan/non-eksperimen karena menjelaskan hubungan kausal antara variabel-variabel melalui pengujian hipotesis tanpa memberikan perlakuan (Singarimbun, 2006) serta dengan sampel yang diambil dari suatu populasi dan menggunakan kuesioner sebagai alat pengumpul data yang pokok dan pada umumnya merupakan unit analisa individu.

Dalam penelitian ini yang digunakan sebagai sampel adalah Pegawai BKKBN Kabupaten Madiun yang berjumlah 32 orang.

\section{ANALISIS DAN PEMBAHASAN}

\section{Analisis}

a. Uji validitas

Pengujian instrumen dilakukan terlebih dahulu sebelum pengujian hipotesis. Pengujian ini menggunakan Pearson Correlation. Item yang valid mempunyai nilai koefisien korelasi $r_{\text {hitung }}$ lebih dari $(\geq) r_{\text {kritis }} 0.30$.

1) Uji validitas variabel Penggunaan Teknologi Informasi

Uji coba kuesioner variabel Penggunaan Teknologi Informasi dilakukan pada 15 orang responden yang terdiri dari pegawai BKKBN Kabupaten Madiun. Dari data scoring setelah dilakukan uji indeks diskriminasi item kuesioner Penggunaan Teknologi Informasi dengan komputasi Software SPSS 16.0 for windows untuk 12 item, 12 item dinyatakan valid.

Tabel 1 Validitas Kuesioner Penggunaan Teknologi Informasi

\begin{tabular}{|l|c|c|c|c|}
\hline \multicolumn{1}{|c|}{ No. } & Item & Koefisien & Signifikan & Kriteria \\
\hline 1. & 1 & 0.788 & 0,000 & Valid \\
\hline 2. & 2 & 0.750 & 0.001 & Valid \\
\hline 3. & 3 & 0.779 & 0.001 & Valid \\
\hline 4. & 4 & 0.801 & 0.000 & Valid \\
\hline 5. & 5 & 0.824 & 0.000 & Valid \\
\hline 6. & 6 & 0.759 & 0.001 & Valid \\
\hline 7. & 7 & 0.864 & 0.000 & Valid \\
\hline 8. & 8 & 0.628 & 0.012 & Valid \\
\hline 9. & 9 & 0.771 & 0.001 & Valid \\
\hline 10. & 10 & 0.686 & 0.005 & Valid \\
\hline 11. & 11 & 0.658 & 0.008 & Valid \\
\hline 12. & 12 & 0.815 & 0.000 & Valid \\
\hline
\end{tabular}


2) Uji validitas variabel Minat Pemanfaatan Teknologi Informasi Uji coba kuesioner variabel Minat Pemanfaatan Teknologi Informasi dilakukan pada 15 orang responden yang terdiri dari pegawai BKKBN Kabupaten Madiun. Dari data scoring setelah dilakukan uji indeks diskriminasi item kuesioner Minat Pemanfaatan Teknologi Informasi dengan komputasi Software SPSS 16.0 for windows untuk 14 item, 14 item dinyatakan valid. Hasil penghitungan indeks diskriminasi item kuesioner Minat Pemanfaatan Teknologi Informasi dijelaskan pada tabel berikut:

Tabel 2 Validitas Kuesioner Minat Pemanfaatan Teknologi Informasi

\begin{tabular}{|l|c|c|c|c|}
\hline \multicolumn{1}{|c|}{ No. } & Item & Koefisien & Signifikan & Kriteria \\
\hline 1. & 1 & 0.908 & 0,000 & Valid \\
\hline 2. & 2 & 0.593 & 0.020 & Valid \\
\hline 3. & 3 & 0.731 & 0.002 & Valid \\
\hline 4. & 4 & 0.819 & 0.000 & Valid \\
\hline 5. & 5 & 0.771 & 0.001 & Valid \\
\hline 6. & 6 & 0.863 & 0.000 & Valid \\
\hline 7. & 7 & 0.684 & 0.005 & Valid \\
\hline 8. & 8 & 0.844 & 0.000 & Valid \\
\hline 9. & 9 & 0.660 & 0.007 & Valid \\
\hline 10. & 10 & 0.825 & 0.000 & Valid \\
\hline 11. & 11 & 0.671 & 0.006 & Valid \\
\hline 12. & 12 & 0.688 & 0.005 & Valid \\
\hline 13. & 13 & 0.790 & 0.000 & Valid \\
\hline 14. & 14 & 0.875 & 0.000 & Valid \\
\hline
\end{tabular}

3) Variabel Kinerja Pegawai

Uji coba kuesioner variabel Kinerja Pegawai dilakukan pada 15 orang responden. Dari data skoring setelah dilakukan uji indeks diskriminasi item kuesioner Kinerja Pegawai BKKBN Kabupaten Madiun dengan komputasi Software SPSS 16.0 for windows untuk 10 item, 10 item dinyatakan valid. Hasil penghitungan indeks diskriminasi item kuesioner Kinerja Pegawai dijelaskan pada tabel berikut:

Tabel 3 Validitas Kuesioner Kinerja Pegawai

\begin{tabular}{|l|c|c|c|c|}
\hline No. & Item & Koefisien & Signifikan & Kriteria \\
\hline 1. & 1 & 0.730 & 0,002 & Valid \\
\hline 2. & 2 & 0.635 & 0.011 & Valid \\
\hline 3. & 3 & 0.566 & 0.028 & Valid \\
\hline 4. & 4 & 0.940 & 0.000 & Valid \\
\hline 5. & 5 & 0.934 & 0.000 & Valid \\
\hline 6. & 6 & 0.703 & 0.003 & Valid \\
\hline 7. & 7 & 0.701 & 0.004 & Valid \\
\hline 8. & 8 & 0.704 & 0.003 & Valid \\
\hline 9. & 9 & 0.957 & 0.000 & Valid \\
\hline 10. & 10 & 0.883 & 0.000 & Valid \\
\hline
\end{tabular}

\section{b. Uji Reliabilitas}

Pengukuran reliabilitas dengan menggunakan bantuan komputasi Software SPSS version 16.0 for windows. Program uji kehandalan dengan menggunakan 
teknik Alpha Cornbach dengan nilai reliabilitas Alpha Cornbach lebih besar $(\geq)$ dari $\mathrm{r}_{\text {kritis }} 0.700$.

1) Reliabilitas variabel Penggunaan Teknologi Informasi

Penghitungan reliabilitas kuesioner variabel Penggunaan Teknologi Informasi dilakukan pada 12 item yang valid, dengan nilai reliabilitas Alpha Cornbach 0.790 , yang berarti lebih besar $(\geq)$ dari $\mathrm{r}_{\text {kritis }} 0.700$ sebagaimana tertera pada tabel berikut:

\section{Tabel $4 \quad$ Uji Reliabilitas Kuesioner Penggunaan Teknologi Informasi}

\begin{tabular}{|c|c|c|c|}
\hline N Item & Alpha & $\mathbf{r}_{\text {kritis }}$ & Kriteria \\
\hline 12 & 0.790 & 0.700 & Reliabel \\
\hline
\end{tabular}

2) Reliabilitas variabel Minat Pemanfaatan Teknologi Informasi

Penghitungan reliabilitas kuesioner variabel Minat Pemanfaatan Teknologi Informasi dilakukan pada 12 item yang valid, dengan nilai reliabilitas Alpha Cornbach 0.790 , yang berarti lebih besar $(\geq)$ dari $r_{\text {kritis }} 0.700$ sebagaimana tertera pada tabel berikut:

\section{Tabel $5 \quad$ Uji Reliabilitas Kuesioner Minat Pemanfaatan Teknologi} Informasi

\begin{tabular}{|c|c|c|c|}
\hline N Item & Alpha & $\mathbf{r}_{\text {kritis }}$ & Kriteria \\
\hline 12 & 0.790 & 0.700 & Reliabel \\
\hline
\end{tabular}

3) Reliabilitas variabel Kinerja Pegawai

Penghitungan reliabilitas kuesioner variabel hasil belajar dilakukan pada 10 item yang valid, dengan nilai reliabilitas Alpha Cornbach 0.801, yang berarti lebih besar $(\geq)$ dari $r_{\text {kritis }} 0.700$ sebagaimana tertera pada tabel berikut:

\section{Tabel 6 Uji Reliabilitas Kuesioner Kinerja}

\begin{tabular}{|c|c|c|c|}
\hline N Item & Alpha & $\mathbf{r}_{\text {kritis }}$ & Kriteria \\
\hline 10 & 0.801 & 0.700 & Reliabel \\
\hline
\end{tabular}

\section{c. Uji Normalitas}

Setelah dilakukan uji Kolmogrov-Smirnov melalui komputasi Software SPSS Version 16.0 for Windows didapat nilai Kolmogrov-Smirnov sebagaimana tabel berikut:

Tabel 7 Uji Normalitas Data

One-Sample Kolmogorov-Smirnov Test

\begin{tabular}{|c|c|c|}
\hline & & $\begin{array}{l}\text { Unstandardized } \\
\text { Predicted Value }\end{array}$ \\
\hline$N$ & & 32 \\
\hline \multirow[t]{2}{*}{ Normal Parameters ${ }^{a}$} & Mean & .7333333 \\
\hline & Std. Deviation & .07289378 \\
\hline \multirow[t]{3}{*}{ Most Extreme Differences } & Absolute & .207 \\
\hline & Positive & .207 \\
\hline & Negative & -.214 \\
\hline Kolmogorov-Smirnov Z & & 1.480 \\
\hline Asymp. Sig. (2-tailed) & & .508 \\
\hline
\end{tabular}




\begin{tabular}{|ll|r|}
\hline \multicolumn{2}{|c|}{ One-Sample Kolmogorov-Smirnov Test } \\
\hline \multicolumn{2}{|c|}{} & $\begin{array}{r}\text { Unstandardized } \\
\text { Predicted Value }\end{array}$ \\
\hline$N$ & Mean & 32 \\
Normal Parameters ${ }^{a}$ & Std. Deviation & .7333333 \\
& Absolute & .07289378 \\
Most Extreme Differences & Positive & .207 \\
& Negative & .207 \\
& & -.214 \\
Kolmogorov-Smirnov Z & & 1.480 \\
Asymp. Sig. (2-tailed) & & .508 \\
\hline & & \\
\end{tabular}

Berdasarkan tabel diatas, nilai K-S Z 1,480 dan $\mathrm{P}_{\text {hitung }} 0.508$ lebih besar dari $(\geq) \mathrm{P}_{\text {kritis }} 0.05$ maka dianggap normal).

\section{d. Uji Multikolinieritas}

Tabel 8 asil Uji Multikolinieritas

\begin{tabular}{|ll|c|c|}
\hline \multicolumn{1}{|c|}{ Variabel Bebas } & VIF & \multicolumn{1}{c|}{ Keterangan } \\
\hline 1. & $\begin{array}{l}\text { Penggunaan Teknologi } \\
\text { Informasi (X1) }\end{array}$ & 2,215 & Non Multikolinieritas \\
\hline 2. & $\begin{array}{l}\text { Minat Pemanfaatan Teknologi } \\
\text { Informasi(X2) }\end{array}$ & 2.215 & Non Multikolinieritas \\
\hline
\end{tabular}

Dari Tabel 8 tersebut dapat diketahui bahwa variabel bebas memiliki nilai VIF < 5,5 sehingga tidak terjadi multikolinieritas, dengan demikian layak digunakan sebagai analisis selanjutnya.

\section{e. Hasil Uji Heteroskedastisitas}

Hasil uji heteroskedatisitas dapat dilihat pada gambar 2 scatterplot berikut ini :

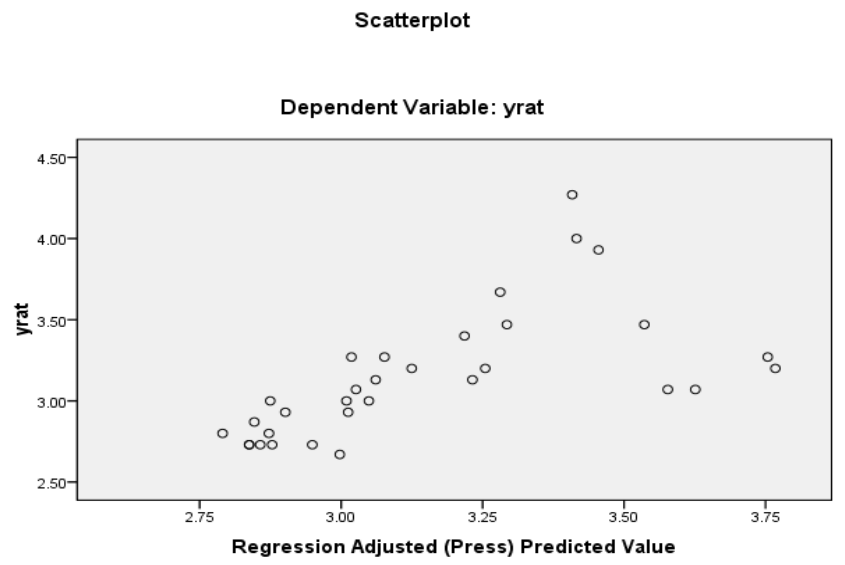

Gambar 1 Hasil Uji Heteroskedastisitas

Pada gambar scatterplot di atas, diketahui semua titik tidak membentuk pola tertentu. Hal ini menunjukkan tidak adanya heteroskedastisitas. 
f. Uji Hipotesis

1) Pengujian terhadap koefisien regresi variabel Penggunaan Teknologi Informasi, nilai t hitung adalah 1,880 dengan tingkat signifikansi sebesar 0,039. Dikarenakan nilai siqnifikasi t nya $<0,05$ maka diperoleh hasil pengujian bahwa bahwa menolak Ho dan menerima Hi. Hal ini disimpulkan bahwa "Terdapat pengaruh secara parsial antara variabel bebas Penggunaan Teknologi Informasi terhadap variabel terikat Kinerja Pegawai BKKBN Kabupaten Madiun (Y).”

2) Pengujian terhadap koefisien regresi variabel Minat Pemanfaatan Teknologi Informasi, nilai $\mathrm{t}$ hitung adalah 2,922 dengan tingkat signifikansi sebesar 0,007. Dikarenakan nilai siqnifikasi t-nya $<0,05$ maka diperoleh hasil pengujian bahwa maka diperoleh hasil pengujian bahwa bahwa menolak Ho dan menerima Hi. Hal ini disimpulkan bahwa "Terdapat pengaruh secara parsial antara variabel bebas Minat Pemanfaatan Teknologi Informasi terhadap variabel terikat Kinerja Pegawai BKKBN Kabupaten Madiun (Y).”

\section{PEMBAHASAN HASIL PENELITIAN}

Ditinjau dari hasil uji-t, yaitu uji secara parsial terbukti bahwa kedua variabel bebas dalam penelitian ini, yaitu: Penggunaan Teknologi Informasi dan Minat Pemanfaatan Teknologi Informasi berpengaruh signifikan secara parsial terhadap variabel terikat Kinerja Pegawai BKKBN Kabupaten Madiun (Y). Hal ini dikarenakan kemampuan serta latar belakang pendidikan pegawai yang mayorias berasal dari lulusan sarjana. Menurut Gibson (1987), ada 3 faktor yang berpengaruh terhadap kinerja, yaitu faktor individu: kemampuan, ketrampilan, latar belakang keluarga, pengalaman kerja, tingkat sosial dan demografi seseorang, faktor psikologis: persepsi, peran, sikap, kepribadian, motivasi dan kepuasan kerja, dan faktor organisasi: struktur organisasi, desain pekerjaan, kepemimpinan, sistem penghargaan (reward system).

Menurut Anwar Prabu Mangkunegara (2000), kinerja (prestasi kerja) adalah hasil kerja secara kualitas dan kuantitas yang dicapai oleh seseorang pegawai dalam melaksanakan tugasnya sesuai dengan tanggung jawab yang diberikan kepadanya. Kinerja merupakan suatu kondisi yang harus diketahui dan dikonfirmasikan kepada pihak tertentu untuk mengetahui tingkat pencapaian hasil suatu instansi dihubungkan dengan visi yang diemban suatu organisasi atau perusahaan serta mengetahui dampak positif dan negatif dari suatu kebijakan operasional. Mink (2003) mengemukakan pendapatnya bahwa individu yang memiliki kinerja yang tinggi memiliki beberapa karakteristik, yaitu diantaranya: (a) berorientasi pada prestasi, (b) memiliki percaya diri, (c) berpengendalian diri, dan (d) kompetensi.

Namun untuk mewujudkan kinerja yang profesional diperlukan berbagai usaha, salah satunya dengan pengembangan diri pegawai dengan memperhatikan perkembangan teknologi informasi. Pada era globalisasi seperti saat ini, pegawai hendaknya berupaya agar dirinya dapat menguasai teknologi informasi, dengan tujuan dapat mengembangkan kemampuan diri yang nantinya dapat dimanfaatkan untuk pengembangan diri dan organisasi dimana dia bekerja. 
Dari uji Beta, diketahui bahwa variabel yang berpengaruh dominan terhadap Kinerja Pegawai adalah variabel Minat Pemanfaatan Teknologi Informasi (X2) dengan nilai beta sebesar 0,453. Hal ini menunjukkan bahwa menurut para pegawai, dalam meningkatkan Kinerja, pimpinan BKKBN sebagai penentu kebijakan hendaknya memperhatikan cara untuk membangkitkan minat Pemanfaatan Teknologi Informasi.

Nilai $\mathrm{R}^{2}$ (koefisien determinasi) sebesar 0,501 berarti bahwa variasi variabel: Penggunaan Teknologi Informasi (X1) dan Minat Pemanfaatan Teknologi Informasi (X2) memberikan kontribusi perubahan terhadap variabel dependen Kinerja (Y) sebesar 50,1\% dan sisanya sebesar 49,9\% dijelaskan oleh variabel-variabel lain diluar model penelitian. Dari sumbangan sebesar $50,1 \%$ tersebut diharapkan dapat memberikan wacana bagi BKKBN dalam meningkatkan kinerja pegawainya.

\section{KESIMPULAN}

\section{Kesimpulan}

Kesimpulan dari penelitian ini adalah:

a. Terdapat pengaruh secara parsial antara variabel bebas Penggunaan Teknologi Informasi terhadap variabel terikat Kinerja Pegawai BKKBN Kabupaten Madiun.

b. Terdapat pengaruh secara parsial antara variabel bebas Minat Pemanfaatan Teknologi Informasi terhadap variabel terikat Kinerja Pegawai BKKBN Kabupaten Madiun.

\section{Keterbatasan}

Dalam penelitian ini, keterbatasan yang dihadapi peneliti adalah:

a. Sampel yang diteliti terbatas pada pegawai BKKBN Kabupaten Madiun. Pemilihan sampel hendaknya lebih luas sehingga dan variatif sehingga dapat memberikan sumbangsih yang lebih luas dan akurat terhadap penelitian selanjutnya.

b. Peneliti hanya mengangkat dua macam variabel independen yang mempengaruhi kinerja. Peneliti selanjutnya hendaknya meneliti variabel lain di luar variabel yang telah diangkat pada penelitian ini, sehingga dapat memberikan alternatif lain terhadap variabel-variabel yang dapat mempengaruhi kinerja.

\section{DAFTAR PUSTAKA}

Amstrong, Mischael, 1999. Manajemen Sumber Daya Manusia. Terjemahan Sofyan dan Haryanto. PT. Elex Media Komputindo. Jakarta.

A.M, Sudirman, 1990, Interaksi dan Motivasi Belajar Mengajar. Jakarta: Raja Grafindo Persada,

Arikunto, Suharsimi. 2002. Prosedur Penelitian Suatu Pendekatan Praktik, PT. Rhineka Cipta, Jakarta.

Azwar, Syaifudin, 2004. Metode Penelitian, Yogyakarta: Pustaka Pelajar.

Bahri Djumarah, Syaiful, Guru dan Anak Dalam Interaksi Edukatif. Jakarta

Bodnar, G, H., and Hopwood, W.S, 1995, Accounting Information Systems. Prentice Hall, Inc. Engelwood Cliffs, New Jersey. 
Davis, F.D, 1989, “Perceived Usefulness, Perceived Ease of Use, and Acceptance of Information System Tecnology, MIS Quarterly, Vol. 13. No. 3, pp. 319-339.

, Bagozzi, R.P., and Warsaw, P.R., 1989, "User Acceptance of Computer Tecnology: A Comparison of Two Theorical Models", Managemen Science,Vol. 39. No. 8, pp. 983-1003.

Febrian, Jack. 2001. Menggunakan Internet. Bandung:Informatika.

Goodhue, Dale L., 1995, "Understanding User Evaluation of Information Systems",Management Science, Vol. 41 No. 12, Hal. 1827-1844. , 2006, Structural Equation Modeling Metode ALternatif dengan Partial Least Square (PLS), Badan Penerbit Universitas Diponegoro, Semarang.

, Ronald L. Thompson, 1995, "Task-Tecnology Fit and Individual Performance”, MIS Quarterly, Vol. 19. No. 2, Hal 213-236.

H. Djaali. 2007. Psikologi Pendidikan. Jakarta: Bumi Akasara.

Handayani, Rini, 2007, "Analisis Faktor-Faktor Yang Mempengaruhi Minat Pemanfaatan Sistem Informasi dan Penggunaan Sistem Informasi", Simposium Nasional Akuntansi X.

Husein, Fakhri, Muhammad, dan Wibowo, Amin, 2000, Sistem Informasi Manajemen, Badan Penerbit UPP AMP YKPN, Yogyakarta.

Hurlock, B.E. 2003. Psikologi Perkembangan: Suatu Pendekatan Sepanjang Rentang Kehidupan. Ed. 5. Jakarta: Erlangga

Indriantoro, Nur dan Bambang Supomo. 2002. "Metodologi Penelitian Bisnis".BPFE, Yogyakarta.

Jogiyanto, 2007, Sistem Informasi Keperilakuan, Penerbit Andi, Yogyakarta.

Jumaili, Salman, 2005, "Kepercayaan Terhadap Teknologi Sistem Informasi Baru Dalam Evaluasi Kinerja Individual”, Simposium Nasional Akuntansi 8, Hal. 722-735.

Jin, Tjhai Fung. 2002. "Analisis Faktor-Faktor yang Mempengaruhi PemanfaatanTeknologi Informasi dan Pengaruh Pemanfaatan Teknologi Informasi Terhadap Kinerja Akuntan Publik". Jurnal Bisnis dan Akuntansi.

Jurnali, Teddy dan Bambang Supomo. 2002. "Pengaruh Faktor Kesesuaian Tugas-Teknologi dan Pemanfaatan TI Terhadap Kinerja Akuntan Publik".JRAI,Vol.5, No.2, Mei 2002.

Kadir, Abdul. 2003. Pengenalan Sistem Informasi. Yogyakarta:Adi Offset.

Kang, Sungmin. 1998. Information Technology Acceptance : Evolving with the Changes

McFarland, L.J., Senn, L.E., and Childess, J.R., 2004, Twenty-First CenturyLeadership: Dialogues with 100 Top Leaders, California: The LeadershipPress.

McKeown, Patrick G., 2001. Information Technology and The Networked Economy, Harcourt: Orlando

Robbins, Stephen P., 1996. Perilaku Organisasi Jilid II, Alih Bahasa Hadayana Pujaatmaka, Jakarta, Prenhalindo.

Sekaran, Uma, 2006, Metodelogi Penelitian Untuk Bisnis, Salemba Empat, Jakarta. 
Singarimbun, M.dan Effendi. 2009. Metode Penelitian Survai, LP3S,Jakarta.

Soekidjo Notoatmodjo, 2003, Pengembangan Sumber Daya Manusia, PT Rineka Cipta, Jakarta

Suprihanto dkk. 2003. Perilaku Organisasional. Sekolah Tinggi Ilmu Ekonomi Yogyakarta: Yogyakarta

Surya, M., 2004, Psikologi Pembelajaran dan Pengajaran, Pustaka Bani. Quraisy, Bandung.

Tampubolon, P. Manahan, 1991, Manajemen Operasional, edisi pertama,. Ghalia Indonesia.

William dan Sawyer. 2003.Using Information Technologi. Yogyakarta:Andi

Warsita, Bambang, 2008. Teknologi Pembelajaran: Landasan dan Aplikasinya. Penerbit Rineka Cipta, Jakarta.

Venkatesh, V., Morris, M. G., Davis, G. B., \& Davis, F. D. (2003). User Acceptance of Information Technology: Toward a Unified View. (C.Beath, Penyunt.) MIS Quarterly 


\title{
PENERAPAN BALANCED SCORECARD SEBAGAI ALAT UKUR KINERJA PADA RUMAH SAKIT UMUM DAERAH Dr.HARJONO PONOROGO
}

\author{
Zaskia Tristiana Anggraini dan Elva Nuraina \\ Program Studi Pendidikan Akuntansi - FPIPS \\ IKIP PGRI MADIUN \\ elvanuraina99@gmail.com
}

\begin{abstract}
ABSTRAK
Rumah Sakit Umum Daerah Dr.Harjono Ponorogo merupakan rumah sakit rujukan pelayanan kesehatan di daerah sekitar Kota Ponorogo. Pengukuran kinerja rumah sakit didasarkan pada standar nasional pelayanan yang sudah ditentukan oleh pemerintah yaitu hanya menilai kinerja dari aspek keuangan. Untuk itu diperlukan adanya pengukuran kinerja dengan menggunakan Balanced Scorecard, dimana alat pengukuran kinerja ini mencakup semua aspek yang kemudian dikelompokkan menjadi empat perspektif utama yaitu: perspektif keuangan, perspektif pertumbuhan dan pembelajaran, perspektif proses bisnis internal, serta perspektif pelanggan. Tujuan penelitian ini adalah untuk mengetahui penerapan balanced scorecard yang ditinjau dari perspektif keuangan, perspektif pelanggan, perspektif proses bisnis internal serta perspektif pembelajaran dan pertumbuhan sebagai alat ukur kinerja pada Rumah Sakit Umum Daerah Dr.Harjono Ponorogo.

Pengujian penelitian ini untuk mengukur kinerja RSUD Dr.Harjono, analisis kinerja dilakukan dengan menggunakan metode Balanced Scorecard yang ditinjau dari perspektif keuangan, perspektif pelanggan, perspektif proses bisnis internal serta perspektif pembelajaran dan pertumbuhan. Pendekatan yang dilakukan dalam penelitian ini adalah melalui penelitian kombinasi dengan jenis data ordinal. Penelitian ini dilakukan dengan menggunakan data primer tahun 2011-2013 pada RSUD Dr.Harjono Ponorogo untuk menganalisis prespektif keuangan, pelanggan, proses bisnis internal, serta prespektif pembelajaran dan pertumbuhan, sedangkan pada tingkat kepuasan karyawan dilakukan analisis melalui kuisioner.

Hasil dari keseluruhan pengukuran kinerja dengan menggunakan balanced scorecard pada RSUD Dr.Harjono Ponorogo pada tahun 2011-2013 berada dalam kondisi Sangat Sehat kategori A dengan total score 76,24\%. Hasil analisis yang dilakukan, dapat diketahui bahwa kinerja RSUD Dr.Harjono menunjukan hasil cukup baik pada prespektif keuangan tapi perlu ditingkatkan pada rasio efisiensi, pada prespektif pelanggan menunjukkan hasil yang cukup baik pada tingkat customer retention namun pada tingkat profitabilitas pelanggan dan customer aquisition menunjukan hasil yang kurang baik, pada prespektif proses bisnis internal menunjukkan hasil cukup baik, demikian juga pada prespektif pembelajaran dan pertumbuhan menunjukkan hasil yang baik dengan tingkat kepuasan karyawan 69,08\%. Dari data penelitian tersebut dapat diambil kesimpulan bahwa dengan menggunakan balanced scorecard, rumah sakit dapat mengukur kinerja dengan lebih komprehensif, sehingga dapat meningkatkan kinerja dimasa yang akan datang.
\end{abstract}

Kata Kunci : Balanced Scorecard, Alat Ukur Kinerja, RSUD Dr.Harjono 


\section{PENDAHULUAN}

Pentingnya pelayanan rumah sakit yang bermutu dan berkualitas harus semakin ditingkatkan seiring dengan semakin meningkatnya pertumbuhan penduduk dan derajat kesehatan masyarakat. Setiap unit usaha dituntut untuk meningkatkan mutu dan bekerja lebih efektif dan efisien agar mendaptkan hasil yang optimal sehingga tetap eksis didunia usaha. Dari segi pelayanan, rumah sakit merupakan organisasi sektor publik yang memberikan pelayanan secara medis.

Menurut Mardiasmo (2002: 2) bahwa istilah "sektor publik" sendiri memiliki pengertian bermacam-macam. Hal tersebut merupakan konsekuensi dari luasnya wilayah publik, sehingga setiap disiplin ilmu (ekonomi, polotik, hukum, dan sosial) memiliki cara pandang dan definisi yang berbeda-beda. Dari sudut pandang ekonomi, sector public dapat dipahami sebagai suatu entitas yang aktivitasnya berhubungan dengan usaha untuk menghasilkan barang dan pelayanan public dalam rangka memenuhi kebutuhan dan hak publik.

Rumah sakit dituntut untuk mampu memberikan pelayanan memuaskan, profesional dengan harga bersaing, sehingga strategi dan kinerja rumah sakit tersebut harus berfokus pada keinginan pelanggan (pasien) tersebut. Penilaian atau pengukuran kinerja merupakan salah satu faktor yang penting dalam perusahaan. Selain digunakan untuk menilai keberhasilan perusahaan, pengukuran kinerja juga dapat digunakan sebagai dasar untuk mengevaluasi hasil kerja dari periode yang lalu.

Selama ini, pengukuran kinerja perusahaan cenderung lebih memfokuskan terhadap sisi keuangan saja. Sementara itu, metode pengukuran kinerja telah berkembang pesat. Pengukuran kinerja perusahaan tidak lagi dianggap baik jika hanya dilihat dari sisi keuangan saja yang tidak mampu mencerminkan kompleksitas dan nilai yang melekat pada perusahaan, karena tidak memperhatikan hal-hal lain di luar finansial, yaitu sisi pelanggan dan karyawan yang merupakan faktor penting bagi perusahaan. Pengukuran kinerja dalam suatu perusahaan tidak hanya dilihat dari segi keuangan saja, tapi akan lebih baik apabila dari segi non keuangan juga diukur untuk memaksimalkan kinerja suatu perusahaan.

Dor dan Maryanne (2009: 366) mengungkapkan bahwa balanced scorecard menerjemahkan misi dan strategi organisasi dalam tujuan operasional dan ukuran kinerja dalam empat perspektif, yaitu perspektif keuangan, perspektif pelanggan, perspektif proses bisnis internal, serta perspektif pembelajaran dan pertumbuhan. Dengan peranan yang dimainkan keempat perspektif ini dalam ukuran kinerja, pengujian perspektif yang lebih detail akan lebih terjamin.

Rumah Sakit Umum Daerah Dr.Harjono Ponorogo merupakan rumah sakit rujukan pelayanan kesehatan di daerah sekitar Kota Ponorogo. Oleh karena itu untuk dapat memberikan pelayanan kesehatan yang berkualitas bagi masyarakat perlu disusun visi, misi, tujuan, sasaran serta indikator keberhasilan yang diselesaikan dalam bentukrencana strategis. Indikator keberhasilan bukan saja dalam bentuk finansial tapi juga dengan indikator yang lain seperti pelangan, bisnis internal juga pembelajaran dan pertumbuhan yang selanjutnya dijadikan bahan untuk mengendalikan arah dan mutu pelayanan kesehatan agar visi yang telah ditetapkan benar-benar dapat diwujudkan.

Pengukuran kinerja rumah sakit didasarkan pada standar nasional pelayanan yang sudah ditentukan oleh pemerintah yaitu hanya menilai kinerja dari 
aspek keuangan. Untuk itu diperlukan adanya pengukuran kinerja dengan menggunakan Balanced Scorecard, dimana alat pengukuran kinerja ini mencakup semua aspek yang kemudian dikelompokkan menjadi empat perspektif utama yaitu: perspektif keuangan, perspektif pertumbuhan dan pembelajaran, perspektif proses bisnis internal, serta perspektif pelanggan. Dari latar belakang di atas, maka dalam penelitian ini peneliti tertarik untuk membahas mengenai "Penerapan Balanced Scorecard Sebagai Alat Ukur Kinerja pada Rumah Sakit Umum Daerah Dr.Harjono Ponorogo".

\section{Tujuan penelitian:}

1. Mengetahui pengukuran kinerja Rumah Sakit Umum Daerah Dr.Harjono.

2. Mengetahui penerapan balanced scorecard yang ditinjau dari perspektif keuangan, perspektif pelanggan, perspektif proses bisnis internal serta perspektif pembelajaran dan pertumbuhan sebagai alat ukur kinerja pada Rumah Sakit Umum Daerah Dr.Harjono Ponorogo.

3. Mengetahui tingkat kepuasan karyawan terhadap kinerja manajemen Rumah Sakit Umum Daerah Dr.Harjono Ponorogo.

4. Menganalisis perbandingan antara pengukuran kinerja tradisional dengan pengukuran kinerja menggunakan Balanced Scorecard.

\section{KAJIAN TEORI}

Moeheriono (2010: 61) berpendapat bahwa kinerja adalah hasil kerja yang dapat dicapai oleh seseorang atau sekelompok orang dalam suatu organisasi baik secara kuantitatif maupun kuaitatif sesuai dengan kewenangan dan tugas tanggungjawab masing-masing dalam upaya mencapai tujuan organisasi bersangkutan secara ilegal, tidak melanggar hukum dan sesuai dengan moral maupun etika.

Pengukuran kinerja (performance measurement) mempunyai penilaian suatu proses penilaian tentang kemajuan pekerjaan terhadap tujuan dan sasaran dalam pengelolaan sumber daya manusia untuk menghasilkan barang dan jasa termasuk efisiensi serta efektivitas tindakan dalam mencapai tujuan organisasi (Moeheriono, 2010: 61). Menurut Mulyadi (2007: 3) bahwa Balanced Scorecard terdiri dari 2 suku kata yaitu kartu nilai (scorecard) dan balanced (berimbang). Pada tahap eksperimen awal, Balanced Scorecard merupakan kartu skor yang dimanfaatkan untuk mencatat skor hasil kerja eksekutif. Melalui kartu skor, skor yang hendak diwujudkan eksekutif di masa depan dibandingkan dengan hasil kinerja sesungguhnya. Hasil perbandingan ini dimanfaatkan untuk melakukan evaluasi atas kinerja eksekutif. Kata berimbang dimaksudkan untuk menunjukkan bahwa kinerja eksekutif diukur secara berimbang dari dua perspektif: keuangan dan nonkeuangan, jangka pendek dan jangka panjang, intern dan ekstern.

Dor dan Maryanne (2009: 366) mengungkapkan bahwa balanced scorecard menerjemahkan misi dan strategi organisasi dalam tujuan operasional dan ukuran kinerja dalam empat perspektif, yaitu perspektif keuangan, perspektif pelanggan, perspektif proses bisnis internal, serta perspektif pembelajaran dan pertumbuhan. Dengan peranan yang dimainkan keempat perspektif ini dalam ukuran kinerja, pengujian perspektif yang lebih detail akan lebih terjamin. Mulyadi (2007: 15) berpendapat bahwa keunggulan pendekatan Balanced 
Scorecard dalam sistem perencanaan strategik yang memiliki karakteristik sebegai berikut :
a. Komprehensif
b. Koheren
c. Berimbang
d. Terukur

\section{METODE PENELITIAN}

Penelitian ini dilakukan pada Rumah Sakit Umum Daerah Dr.Harjono karena merupakan rumah sakit rujukan pelayanan kesehatan di daerah sekitar Kota Ponorogo, oleh karena itu harus dapat memberikan pelayanan kesehatan yang berkualitas bagi masyarakat yang sesuai dengan visi, misi, tujuan strategis.

Pendekatan penelitian dilakukan adalah melalui penelitian Kombinasi. Jenis data yang digunakan adalah data ordinal. Menurut Sugiyono (2013: 28) bahwa data ordinal merupakan data kuantitatif yang berbentuk peringkat atau rangking. Menurut Sugiyono (2013: 271) bahwa metode penelitian kombinasi adalah suatu metode penelitian yang mengkombinasikan atau menggabungkanantara metode kuantitatif dan metode kualitatif untuk digunakan secara bersama-sama dalam suatu kegiatan penelitian, sehingga diperoleh data yang lebih komprehensif, valid, reliabel dan objektif.

Sumber data yang digunakan dalam penelitian ini berupa data primer dan data sekunder. Sumber data primer yang digunakan dalam penelitian ini diperoleh dari hasil wawancara dengan pihak perusahaan, data perusahaan seperti data laporan keuangan, anggaran pendapatan dan pengeluaran, data jumlah pasien (lama, baru, hidup dan mati), jumlah tempat tidur, data jumlah karyawan, serta dari hasil penyebaran kuisioner yang dilakukan peneliti. Sedangkan sumber data sekunder yang digunakan dalam penelitian ini seperti visi, misi dan sejarah berdirinya rumah sakit(www.rsudrharjono.or.id).

Metode yang digunakan untuk mengumpulkan data yaitu dengan menggunakan metode kuesioner, wawncara, observasi, dokumentasi dan studi pustaka. Koesioner yang disebarkan kepada karyawan rumah sakit digunakan untuk mengukur kepuasan karyawan dalam perspektif pembelajaran dan pertumbuhan, tehnik keabsahan data yang digunakaaaaan adalah menggunakan uji validitas dan reliabilitas. Teknik analisis data yang digunakan adalah:

1. Perspektif Keuangan, Rasio yang digunakan adalah:

a. Rasio ekonomis.

b. Rasio efisiensi.

c. Rasio efektivitas.

2. Perspektif Pelanggan

a. Tingkat profitabilitas pelanggan.

b. Kemampuan mempertahankan pelanggan (Customer Retention).

c. Kemampuan meraih pelanggan baru (Customer Aquisition).

3. Perspektif Proses Bisnis Internal, rantai nilai proses terdiri dari dua proses yaitu:

a. Proses Inovasi.

b. Proses Operasional. 
4. Perspektif Pembelajaran Dan Pertumbuhan, ukuran kinerja yang dipakai adalah:
a. Kepuasan karyawan.
b. Retensi karyawan.
c. Produktivitas karyawan.

\section{PEMBAHASAN}

Konsep balanced scorecard dalam mengukur kinerja RSUD Dr.Harjono Ponorogo yang menggunakan empat prespektif yaitu: prespektif keuangan, pelanggan, proses bisnis internal serta pertumbuhan dan pembelajaran, dari tiaptiap prespektif balanced scorecard tersebut, terdapat beberapa strategi yang diperoleh dari observasi dan wawancara dengan beberapa bagian di RSUD Dr.Harjono Ponorogo.

1. Perspektif Keuangan

Tabel 1 Rekapitulasi perhitungan rasio ekonomi RSUD Dr.Harjono Ponorogo

tahun 2011-2013

\begin{tabular}{|l|l|l|l|l|}
\hline \multirow{2}{*}{ Tahun } & Realisasi & Anggaran & $\begin{array}{l}\text { Rasio } \\
\text { Ekonomi }(\%)\end{array}$ & $\begin{array}{l}\text { Naik/Turun } \\
(\%)\end{array}$ \\
\cline { 2 - 5 } & $(1)$ & $(2)$ & $(3)=(1):(2)$ & \\
\hline 2011 & 43.523 .654 .638 & 43.429 .033 .000 & $100,22 \%$ & - \\
\hline 2012 & 80.211 .062 .540 & $78.255 .197 .877,21$ & $102,50 \%$ & Naik 2,28\% \\
\hline 2013 & 96.246 .670 .583 & $98.525 .499 .535,06$ & $97,69 \%$ & Turun $4,81 \%$ \\
\hline
\end{tabular}

Sumber: Data yang diolah

Tabel 2 Rekapitulasi perhitungan rasio efisiensi RSUD Dr.Harjono tahun 2011-2013

\begin{tabular}{|l|l|l|l|l|}
\hline \multirow{2}{*}{ Tahun } & Realisasi Biaya & $\begin{array}{l}\text { Realiasai } \\
\text { Pendapatan }\end{array}$ & $\begin{array}{l}\text { Rasio } \\
\text { Efisiensi }(\%)\end{array}$ & $\begin{array}{l}\text { Naik/Turun } \\
(\%)\end{array}$ \\
\cline { 2 - 5 } & $(1)$ & $(2)$ & $(3)=(1):(2)$ & \\
\hline 2011 & 43.523 .654 .638 & $28.657 .395 .879,83$ & $151,88 \%$ & - \\
\hline 2012 & 80.211 .062 .540 & $60.209 .097 .247,85$ & $133,21 \%$ & Naik 18,67\% \\
\hline 2013 & 96.246 .670 .583 & $68.006 .102 .818,85$ & $141,52 \%$ & Naik 8,31\% \\
\hline
\end{tabular}

Sumber: Data yang diolah

Tabel 3 Rekapitulasi perhitungan rasio efektivitas RSUD Dr.Harjono Ponorogo tahun 2010-2012

\begin{tabular}{|c|l|l|l|l|}
\hline \multirow{2}{*}{ Tahun } & \multicolumn{1}{|c|}{$\begin{array}{c}\text { Anggaran } \\
\text { Pendapatan }\end{array}$} & $\begin{array}{l}\text { Realisasi } \\
\text { Pendapatan }\end{array}$ & $\begin{array}{l}\text { Rasio } \\
\text { Efektivitas }\end{array}$ & $\begin{array}{l}\text { Naik/Turun } \\
(\%)\end{array}$ \\
\cline { 2 - 4 } & $(1)$ & $(2)$ & $(3)=(1):(2)$ & \\
\hline 2011 & 26.584 .362 .000 & $28.657 .379,83$ & $92,77 \%$ & - \\
\hline 2012 & 49.000 .000 .000 & $60.209 .097 .247,85$ & $81,38 \%$ & $\begin{array}{l}\text { Turun } \\
11,39 \%\end{array}$ \\
\hline 2013 & $68.006 .102 .818,85$ & 60.000 .000 .000 & $88,22 \%$ & Naik 6,84\% \\
\hline
\end{tabular}

Sumber: Data yang diolah 
2. Perspektif Pelanggan

Tabel 4 Rekapitulasi hasil pengukuran Kinerja Prespektif Pelanggan RSUD

Dr.Harjono Ponorogo tahun 2011 - 2013

\begin{tabular}{|c|c|c|c|c|c|c|}
\hline \multirow[b]{2}{*}{ Tahun } & \multicolumn{6}{|l|}{ Ukuran } \\
\hline & $\begin{array}{c}\text { Profitabilitas } \\
\text { Pelanggan } \\
\end{array}$ & $\begin{array}{l}\text { Naik } \\
\text { /turun }\end{array}$ & $\begin{array}{l}\text { Customer } \\
\text { Retention }\end{array}$ & $\begin{array}{l}\text { Naik } \\
\text { /turun }\end{array}$ & $\begin{array}{l}\text { Costomer } \\
\text { Aquisition }\end{array}$ & $\begin{array}{l}\text { Naik } \\
\text { /turun }\end{array}$ \\
\hline \multirow[b]{2}{*}{2011} & $96,66 \%$ & - & $59,08 \%$ & - & $62,87 \%$ & - \\
\hline & $95,72 \%$ & $-0,94 \%$ & $156,80 \%$ & $+97,72 \%$ & $38,90 \%$ & - \\
\hline \multirow{2}{*}{2012} & $95,60 \%$ & $-0,12 \%$ & $166,96 \%$ & $+10,16 \%$ & & 23,97 \\
\hline & & & & & $37,46 \%$ & \\
\hline 2013 & & & & & & $-\overline{1,44 \%}$ \\
\hline
\end{tabular}

Sumber: data diolah peneliti

3. Perspektif Proses Bisnis Internal

Tabel 5 Proses Inovasi RSUD Dr.Harjono Ponorogo tahun 2011-2013

\begin{tabular}{|l|c|c|c|}
\hline Tahun & Pendapatan Jasa Baru & Total Pendapatan & Inovasi (\%) \\
\hline 2011 & $\operatorname{Rp~} 896.784 .812,6$ & $\operatorname{Rp} 28.896 .159 .079,83$ & $3,10 \%$ \\
\hline 2012 & $\operatorname{Rp~} 1.991 .353 .661 .43$ & $\operatorname{Rp~} 49.749 .811 .097,45$ & $4,002 \%$ \\
\hline 2013 & $\operatorname{Rp} 3.030 .979 .381,48$ & $\operatorname{Rp~72.894.843.928,26~}$ & $4,15 \%$ \\
\hline
\end{tabular}

Sumber: RSUD Dr.Harjono Ponorogo yang telah diolah

Pada proses operasional, pengukuran kinerja menggunakan skor 1 yang berarti baik dan -1 yang berarti kurang baik

Tabel 6 Skor pengukuran kinerja RSUD Dr.Harjono

\begin{tabular}{|c|c|}
\hline Indikator & Skor \\
\hline Rawat Jalan & -1 \\
\hline Rawat Inap & 1 \\
\hline BOR & 1 \\
\hline ALOS & -1 \\
\hline TOI & 1 \\
\hline BTO & -1 \\
\hline GDR & 1 \\
\hline NDR & 1 \\
\hline Total Skor & $\mathbf{2}$ \\
\hline
\end{tabular}

Sumber : Data sekunder diolah

4. Perspektif Pembelajaran dan Pertumbuhan

Tabel 7 Rekapitulasi hasil pengukuran Kinerja Perspektif Pembelajaran dan Pertumbuhan RSUD Dr.Harjono tahun 2011 - 2013

\begin{tabular}{|l|l|l|c|}
\hline \multirow{2}{*}{ Tahun } & Ukuran & \multicolumn{3}{|l|}{$\begin{array}{l}\text { Kepuasan } \\
\text { karyawan }\end{array}$} & $\begin{array}{l}\text { Retensi } \\
\text { karyawan }\end{array}$ & Produktivitas karyawan \\
\hline 2011 & - & $1,2 \%$ & $\mathrm{Rp} \mathrm{58.024.415,8}$ \\
\hline 2012 & - & $0,86 \%$ & $\mathrm{Rp} \mathrm{86.371.199,81}$ \\
\hline 2013 & $69,08 \%$ & $0,85 \%$ & $\mathrm{Rp} \mathrm{124.182.016,9}$ \\
\hline
\end{tabular}

Sumber: data diolah peneliti 
Dengan indeks kepuasan yang dihasilkan demikian maka pengukuran kepuasan karyawan RSUD Dr.Harjono masuk dalam kategori puas untuk kebijakan perusahaan, gaji maupun keseluruhan perusahaan.

Hasil pengukuran kinerja perusahaan dengan Balanced Scorecard Tabel 8 Pengukuran Bobot Indikator dan Skor Tertimbang maksimal

\begin{tabular}{|c|c|c|c|c|c|c|}
\hline Prespektif & $\begin{array}{c}\text { Indikator } \\
\text { Kerja }\end{array}$ & $\begin{array}{c}\text { Jumlah } \\
\text { Indikator }\end{array}$ & Bobot & $\begin{array}{c}\text { Bobot } \\
\text { Indikator }\end{array}$ & $\begin{array}{c}\text { Skor } \\
\text { Indikator }\end{array}$ & $\begin{array}{c}\text { Skor } \\
\text { Tertimbang } \\
\text { Maksimal }\end{array}$ \\
\hline \multirow{3}{*}{ Keuangan } & R.Ekonomi & 3 & 26 & 8,66 & 4 & 103,92 \\
\hline & R.Efisiensi & & & & & \\
\hline & R.Efektivitas & & & & & \\
\hline \multirow{3}{*}{ Pelanggan } & Prifitabilitas & 3 & 25 & 8,33 & 4 & 99,96 \\
\hline & Retention & & & & & \\
\hline & Aquisition & & & & & \\
\hline \multirow{2}{*}{$\begin{array}{l}\text { Proses Bisnis } \\
\text { Internal }\end{array}$} & Inovasi & 2 & 24 & 12 & 4 & 96 \\
\hline & Operasional & & & & & \\
\hline \multirow{3}{*}{$\begin{array}{l}\text { Pembelajaran } \\
\text { dan } \\
\text { Pertumbuhan }\end{array}$} & Kepuasan & 3 & 25 & 8,33 & 4 & 99,96 \\
\hline & Retensi & & & & & \\
\hline & Produktivitas & & & & & \\
\hline \multicolumn{3}{|c|}{ Total } & 100 & & & 399,84 \\
\hline
\end{tabular}

Sumber: Data diolah peneliti

Tahap selanjutnya adalah mengukur jumlah skor indikator keuangan dan memebrikan nilai $\mathrm{A}=4, \mathrm{~B}=3, \mathrm{C}=2, \mathrm{D}=1$ dan untuk perspektif keuangan ditentukan sebagai berikut:

1. Nilai target rasio ekonomi $=175 \%$

Nilai minimum $=0$

Interval kelas rasio ekonomi $=(175-0) / 3=58,33 \%$

Jadi kriteria skor indikator rasio ekonomi adalah:

$\mathrm{A}=116,67 \%-175 \%$

$\mathrm{B}=58,34 \%-<116,67 \%$

$\mathrm{C}=0,01 \%-<58,34 \%$

$\mathrm{D}=<0,01 \%$

2. Nilai target rasio efisiensi $=35 \%$

Nilai minimum $=0$

Interval kelas rasio efisiensi $=(35-0) / 3=11,66 \%$

Jadi kriteria skor indikator rasio efisiensi adalah:

$\mathrm{A}=23,34 \%-35 \%$

$\mathrm{B}=11,68 \%-<23,34 \%$

$\mathrm{C}=0,02 \%-<16,68 \%$

$\mathrm{D}=<0,02 \%$

3. Nilai target rasio efektivitas $=40 \%$

Nilai minimum $=0$

Interval kelas rasio efektivitas $=(40-0) / 3=13,33 \%$

Jadi kriteria skor indikator rasio efektivitas adalah:

$\mathrm{A}=26,67 \%-40 \%$

$\mathrm{B}=13,34 \%-<26,67 \%$

$\mathrm{C}=0,01 \%-<13,34 \%$

$\mathrm{D}=<0,01 \%$ 
Tabel 9 Nilai Untuk Masing-Masing Indikator Dalam Perspektif Balanced Scorecard RSUD Dr.Harjono Tahun 2011- 2013

\begin{tabular}{|c|c|c|c|c|c|c|}
\hline \multirow{2}{*}{ Prespektif } & \multicolumn{3}{|l|}{ Tahun } & \multirow{2}{*}{$\begin{array}{l}\text { Rata- } \\
\text { rata }\end{array}$} & \multirow{2}{*}{$\begin{array}{l}\text { Nila } \\
\text { i }\end{array}$} & \multirow{2}{*}{$\begin{array}{l}\text { Skor } \\
\text { Indokator }\end{array}$} \\
\hline & 2011 & 2012 & 2013 & & & \\
\hline \multicolumn{7}{|l|}{ Keuangan: } \\
\hline Rasio Ekonomi & $100,22 \%$ & $102,50 \%$ & $97,69 \%$ & $100,13 \%$ & $\mathrm{~B}$ & 3 \\
\hline Rasio Efisiensi & $151,88 \%$ & $133,21 \%$ & $141,52 \%$ & $142,20 \%$ & $\mathrm{~A}$ & 4 \\
\hline $\begin{array}{l}\text { Rasio } \\
\text { Efektivitas }\end{array}$ & $92,77 \%$ & $81,38 \%$ & $88,22 \%$ & $87,45 \%$ & $\mathrm{~B}$ & 3 \\
\hline \multicolumn{6}{|l|}{ Total } & 10 \\
\hline \multicolumn{7}{|l|}{ Pelanggan: } \\
\hline Profitabilitas & $96,66 \%$ & $95,72 \%$ & $95,60 \%$ & $95,99 \%$ & $\mathrm{~B}$ & 3 \\
\hline $\begin{array}{l}\text { Customer } \\
\text { Retention }\end{array}$ & $59,08 \%$ & $156,80 \%$ & $166,96 \%$ & $127,61 \%$ & $\mathrm{~A}$ & 4 \\
\hline $\begin{array}{l}\text { Customer } \\
\text { Aquisition }\end{array}$ & $62,87 \%$ & $38,90 \%$ & $37,46 \%$ & $46,41 \%$ & $\mathrm{C}$ & 2 \\
\hline \multicolumn{6}{|l|}{ Total } & 9 \\
\hline \multicolumn{7}{|l|}{$\begin{array}{l}\text { Bisnis } \\
\text { Internal: }\end{array}$} \\
\hline Inovasi & $3,10 \%$ & $4,002 \%$ & $4,15 \%$ & $3,75 \%$ & $\mathrm{C}$ & 2 \\
\hline Operasional & & & & & $\mathrm{B}$ & 3 \\
\hline \multicolumn{6}{|l|}{ Total } & 5 \\
\hline \multicolumn{7}{|l|}{$\begin{array}{l}\text { Pembelajaran } \\
\text { \& } \\
\text { Pertumbuhan: }\end{array}$} \\
\hline Kepuasan & & & $69,08 \%$ & & $\mathrm{~B}$ & 3 \\
\hline Retensi & $1,2 \%$ & $0,86 \%$ & $0,85 \%$ & $4,57 \%$ & $\mathrm{~B}$ & 3 \\
\hline Produktivitas & $\begin{array}{l}\mathrm{Rp} \\
58.024 .415,8\end{array}$ & $\begin{array}{l}\mathrm{Rp} \\
86.371 .199 \\
81\end{array}$ & $\begin{array}{l}\mathrm{Rp} \\
124.182 .0 \\
16,9\end{array}$ & & A & 4 \\
\hline Total & & & & & & 10 \\
\hline
\end{tabular}

Sumber: Data diolah peneliti

Tahap selanjutnya adalah menghitung jumlah skor tertimbang dengan mengalikan jumlah skor indikator dengan bobot indikator sehingga hasilnya dapat dilihat seperti pada tabel dibawah ini:

Tabel 10 Jumlah Skor Tertimbang

\begin{tabular}{|l|l|l|l|}
\hline Prespektif & $\begin{array}{l}\text { Jumlah Skor } \\
\text { Tertimbang }\end{array}$ & Bobot indicator & Skor \\
\hline Keuangan & 10 & 8,66 & 86,6 \\
\hline Pelanggan & 9 & 8,33 & 74,97 \\
\hline Bisnis internal & 5 & 12 & 60 \\
\hline $\begin{array}{l}\text { Pembelajaran \& } \\
\text { Pertumbuhan }\end{array}$ & 10 & 8,33 & 83,3 \\
\hline Jumlah Skor Tertimbang & 304,87 \\
\hline
\end{tabular}

Sumber: Data diolah peneliti

Selanjutnya, jumlah skor tertimbang tersebut digunakan untuk menghitung nilai akhir total score. Dan untuk menghitung nilai akhir total atau total score digunakan rumus $=($ jumlah skor tertimbang $/$ jumlah skor tertimbang maksimum $)$ 
x 100\%. Sehingga diperoleh hasil total score $=(304,87 / 399,84) \times 100 \%=76,24$

$\%$. Kemudian dilihat dari kriteria standar:

Tabel 11 Kriteria Standar Penilaian

\begin{tabular}{|l|l|l|}
\hline Kondisi & Kategori & Total score \\
\hline SANGAT SEHAT & AAA & $\geq 95$ \\
\cline { 2 - 3 } & AA & $80<\mathrm{TS}<95$ \\
\cline { 2 - 3 } & $\mathrm{A}$ & $65<\mathrm{TS}<80$ \\
\hline \multirow{3}{*}{ KURANG SEHAT } & $\mathrm{BBB}$ & $50<\mathrm{TS}<65$ \\
\cline { 2 - 3 } & $\mathrm{BB}$ & $40<\mathrm{TS}<50$ \\
\cline { 2 - 3 } & $\mathrm{B}$ & $30<\mathrm{TS}<40$ \\
\hline TIDAK SEHAT & $\mathrm{CCC}$ & $20<\mathrm{TS}<30$ \\
\cline { 2 - 3 } & $\mathrm{CC}$ & $10<\mathrm{TS}<20$ \\
\cline { 2 - 3 } & $\mathrm{C}$ & $\mathrm{TS}<10$ \\
\hline
\end{tabular}

Sumber: Rangkuti Freddy (2011: 147)

Maka dapat ditarik kesimpulan hasil pengukuran kinerja dengan menggunakan Balanced Scorecard pada RSUD Dr.Harjono Ponorogo diperoleh nilai dengan total score 76,24\% sehingga masuk dalam kondisi Sangat Sehat kategori A.

\section{KESIMPULAN}

\section{Simpulan}

RSUD Dr.Harjono Ponorogo memungkinkan untuk menerapkan balanced scorecard karena hasil pengukuran kinerja yang dihasilkan peneliti di RSUD Dr.Harjono Ponorogo dengan menggunakan balance scorecard, dapat disimpulkan bahwa:

1. Hasil dari keseluruhan pengukuran kinerja dengan menggunakan balanced scorecard pada RSUD Dr.Harjono Ponorogo pada tahun 2011 sampai 2013 berada dalam kondisi Sangat Sehat kategori A dengan total score $76,24 \%$. Kategori puas tersebut didukung dengan peningkatan koordinasi, konsolidasi sesama karyawan, pemerintah dan lembaga masyarakat untuk mencapai kepentingan bersama melalui kerjasama dan komunikasi yang efektif. Peningkatan pengetahuan, kemampuan dan ketrampilan karyawan rumah sakit baik medis, paramedis maupun tenaga yang lain melalui pendidikan dan pelatihan baik didalam maupun diluar rumah sakit sebagai penghargaan terhadap prestasi kerja dan motivasi bekerja lebih baik dari sebelumnya.

2. Hasil pengukuran kinerja berdasarkan empat perspektif, yaitu:

a. Hasil pengukuran perspektif keuangan, yaitu Rasio Ekonomi dan Rasio Efektivitas menunjukkan hasil yang baik sedangkan Rasio Efisiensi menunjukkan hasil yang kurang baik karena realisasi biaya lebih besar dari tahun 2011-2013. Realisasi biaya tersebut digunakan untuk pemenuhan Belanja Operasi dan Belanja Modal.

b. Hasil pengukuran perspektif pelanggan, menunjukkan hasil yang baik pada tingkat Customer Retention karena dapat mempertahankan pelanggan dari tahun 2011-2013, namun pada tingkat Profitabilitas Pelanggan dan Customer Aquisition menunjukan hasil yang kurang baik karena terjadi penurunan persentase dari tahun 2011-2013, karena adanya perubahan tarif baru RSUD sehingga berpengaruh pada 
pendapatan dan juga ada keluhan pasien tentang kualitas pelayanan petugas.

c. Hasil pengukuran perspektif Proses Bisnis Internal, pada proses inovasi menunjukkan peningkatan persentase dari tahun 2011-2013, ini berarti hasilnya cukup baik karena setiap tahun selalu ada tambahan jasa baru dan juga pada proses operasional menunjukkan hasil yang cukup baik karena sudah sesuai dengan angka ideal yang ditetapkan.

d. Hasil pengukuran perspektif pembelajaran dan pertumbuhan juga menunjukkan hasil yang baik, dengan tingkat kepuasan karyawan $69,08 \%$, tingkat produktivitas karyawan juga menunjukkan hasil yang baik, hal ini dipengaruhi dari total pendapatan dan jumlah karyawan yang selalu meningkat dan juga melihat persentase tingkat retensi karyawan yang menurun dari tahun 2011-2013, tingkat persentase yang semakin menurun menunjukkan hasil yang cukup baik karena berarti jumlah karyawan meningkat sedangkan karyawan yang keluar berkurang.

3. Pengukuran kinerja RSUD Dr.Harjono dengan menggunakan balanced scorecard periode 3 tahun menunjukkan hasil yang berbeda dengan pengukuran kinerja secara tradisional yang dilakukan RSUD Dr.Harjono. dengan balanced scorecard, rumah sakit dapat mengukur kinerja dengan lebih komprehensif, sehingga dapat meningkatkan kinerja dimasa yang akan datang.

\section{Saran}

Berdasarkan hasil analisis dan kesimpulan yang diperoleh, saran-saran yang diajukan bagi penelitian-penelitian selanjutnya adalah:

1. Perspektif keuangan pada tingkat rasio efisiensi harus lebih memperhatikan pengeluaran biaya sehingga bila diperbandingkan tidak jauh lebih besar dari realisasi pendapatan yang ada yaitu dengan cara mengarahkan biaya untuk belanja kegiatan program-program RSUD Dr.Harjono yang dinilai prioritas dan sangat mendesak untuk segera direalisasikan.

2. Dari perspektif pelanggan, perlu meningkatkan profitabilitas pelanggan dengan lebih meningkatkan pelayanan kesehatan dan perlu meningkatkan tingkat pemerolehan pelanggan mengingat angka prosentase customer aquisition yang menurun pada tahun 2011-2013 salah satunya dengan menetapkan kebijakan yang dapat menarik minat pelanggan.

\section{DAFTAR PUSTAKA}

Bestari Dwi Handayani. 2011. Pengukuran Kinerja Rumah Sakit Umum Daerah dengan Pendekatan Balance Scorecard. Jurnal Dinamika Manajemen, 3(1): 74-89.

Dor Hansen dan Maryanne M. Mowen. 2009. Akuntansi Manajerial. Jakarta: Salemba Empat.

Freddy, Rangkuti. 2011. SWOT Balanced Scorecard (Teknik Menyusun Strategi Korporat yang Efektif plus Cara Mengeola Kinerja dan Risiko). Jakarta: Gramedia Pustaka Utama. 
Gaspersz, Vincent. 2003. Sistem Manajemen Kinerja Terintegrasi Balanced Scorecard Dengan Six Sigma Untuk Organisasi Bisnis Dan Pemerintah. Jakarta: PT Gramedia Pustaka Utama.

Imam Ghozali. 2006. Aplikasi Analisis Multivariate dengan Program SPSS. Semarang: Badan Penerbit Universitas Diponegoro.

Mardiasmo. 2002. Akuntansi Sektor Publik. Yogyakarta: ANDI Yogyakarta.

Moeheriono. 2010. Pengukuran Kinerja Berbasis Kompetensi. Bogor: Ghalia Indonesia.

Mulyadi. 2007. Sistem Terpadu Pengelolaan Kinerja Personel Berbasis Balanced Scorecard. Yogyakarta: Sekolah Tinggi Ilmu Manajemen YKPN.

Ni Ketut Rasmini, Ni Luh Supadmi, dan Ni Luh Putu Herawati Sucandra. 2009. Penilaian Kinerja Badan Rumah Sakit Umum Tabanan Berdasarkan Balanced Scorecard. Jurnal (Online), (http://ojs.unud.ac.id, Diunduh 20 Januari 2014).

Sugiyono. 2010. Metode Penelitian Pendidikan (Pendekatan Kuantitatif, Kualitatif, dan $R \& D)$. Bandung: Alfabeta,cv.

Sugiyono. 2011. Metode Penelitian Kuantitatif dan Kualitatif dan $R \& D$. Bandung: Alfabeta Bandung.

Sugiyono. 2013. Cara mudah menyusun: SKRIPSI, TESIS dan DISERTASI. Bandung: Alfabeta,cv.

Suharsimi Arikunto. 2010. Prosedur Penelitian Suatu Pendekatan Praktik. Jakarta: RINEKA CIPTA.

Wibowo. 2007. Manajemen Kinerja. Jakarta: PT Raja Grafindo Persada.

Yuwono Sony dkk. 2004. Petunjuk Praktis Penyusunan Balance Scorecard (Menuju Organisasi Yang Berfokus Pada Strategi). Jakarta: Gramedia Pustaka Utama. 